\title{
The Impact of Road Transport on $\mathrm{CO}_{2}$ Atmospheric Concentrations in Gaza City (Palestine), and Urban Vegetation as a Mitigation Measure
}

\author{
Mohammed Zedan Salem ${ }^{1 *}$, Rania F. Almuzaini ${ }^{2}$, Yasser S. Kishawi ${ }^{3}$ \\ ${ }^{1}$ Department of Business and Finance Management, University College of Applied Sciences (UCAS), \\ Gaza City, Palestine \\ ${ }^{2}$ Department of Planning and Information Systems, University College of Applied Sciences (UCAS), \\ Gaza City, Palestine \\ ${ }^{3}$ Water Authority, Gaza City, Palestine
}

Received: 19 February 2017

Accepted: 12 March 2017

\begin{abstract}
Although traffic-borne pollution has been increasing recently in Gaza City (GC), no studies have tackled the issue in a quantitative manner. This study investigated quantitatively the atmospheric carbon dioxide $\left(\mathrm{CO}_{2}\right)$ concentrations in three heavily-trafficked streets ( device. Measurements were performed during a weekday and a weekend in three specific times, including two rush hours. Green-cover was investigated using the top-down approach for photo interpretation in the selected sites. Furthermore, the awareness of the local population toward greening their streets was tested using two questionnaires. Measured atmospheric $\mathrm{CO}_{2}$ concentrations ranged between $300 \mathrm{ppm}$ and $900 \mathrm{ppm}$ in all selected sites. Atmospheric $\mathrm{CO}_{2}$ concentrations were highest in site $\mathrm{X}$ and lowest in Y. Green-cover percentage was found to be $2 \%, 3 \%$, and $8 \%$ for sites X, Y, and Z, respectively. Generally, higher levels were detected during the working day compared to those detected during the weekend. Additionally, high atmospheric $\mathrm{CO}_{2}$ concentrations were detected in streets with reduced green-cover as well as streets with workshops flanked on both sides. The questionnaires' analysis illustrated sound awareness among respondents regarding the researched aspect.
\end{abstract}

Keywords: carbon dioxide, traffic-borne pollution, transportation means, urban vegetation

*e-mail: mrdd_salem@hotmail.com 


\section{Introduction}

Urban air pollution has become an increasingly important environmental issue in both developed and developing countries. It has been estimated that 1 billion people are exposed to outdoor air pollution annually, and that around 3.7 million die as a direct result of this exposure [1-4], making air pollution the largest single environmental health risk.

Since the industrial revolution air quality has been on the decline due to increased levels of greenhouse gas (GHG) emissions [5-9], and is experienced more in regions with higher levels of socio-economic deprivation [10-11]. Greater differences can be seen if individual countries are compared as well as within the same country.

In densely populated areas transportation means are identified as a major source of trace gases and pollutants, accounting for $70 \%$ of air pollution [12-18]. The main product of fuel burning is $\mathrm{CO}_{2}$ (the most important anthropogenic GHG), but a wide series of other gases is emitted concurrently [19-23]. Although $\mathrm{CO}_{2}$ is considered to be a non-toxic gas, exposure to high concentrations can induce health risks. Furthermore, it is believed to be the main driving factor of global warming [24-26].

Globally, transportation means account for $16 \%$ of the total atmospheric $\mathrm{CO}_{2}$ emissions from fossil fuel use. In Europe and the USA it accounts for an approximate of $24 \%$ and $27 \%$, respectively, of the latter [27-33]. As for the Middle East, it is currently a small contributor to the world's atmospheric $\mathrm{CO}_{2}$ emissions. However, it is noted to be in continuous increase and is further predicted to grow threefold by 2030. This is basically attributed to rapid urbanization, increased car ownership, and a lower modal share of public transport [34-37] .

Urban vegetation has been proven to act as "carbon sinks" that remove $\mathrm{CO}_{2}$ through dry deposition and carbon sequestration and storage [38-53]. However, the type, size, quality, type, and shape of vegetation all influence the level of impact [54-57]. Even though less prosperous communities have more to gain from adding trees, they often have got less space available for them.

Evidence discussed has led many developed countries to formulate and/or enforce strict environmental policies and regulations to enhance air quality [58]. This includes the Clean Air Act of 1963 in the USA and Air Quality Directives developed for the European Union (EU) [59]. Conversely, such efforts and policies are yet to be adopted in most developing countries.

Poor air quality in GC (Palestine; Fig. 1) has been experienced by Gazans for decades. This is mainly due to the rapid population growth, estimated at 3.3\% [60], and the expanding number of transportation means (estimated at about 72,000) [61], in addition to water treatment projects and the overuse of generators to compensate for electricity shortages [62]. The unstable political conditions have contributed toward the worsening of the problem [63-70]. Furthermore, poor air quality within the region is caused by the toxic gases produced by Israeli factories and is consequently transferred to the Palestinian airspace by wind [71].

Green areas in this restricted and heavily urbanized area are progressively decreasing, mainly due to the ongoing political conflict. A total of $30 \%$ of agricultural land in the Gaza Strip (GS) is assessed to be inaccessible as it lies within the "Security Buffer Zone" imposed by the Israeli side [72]. Furthermore, many agricultural lands have been completely bulldozed in the recent IMOs. According to the Ministry of Agriculture statistics, 3.7 million trees and more than 70,000 dunums (equivalent to $1,000 \mathrm{~m}^{2}$ ) have been destroyed in the GS since the beginning of the second Intifada (the second Palestinian uprising against Israel) in 2000 [73]. Other current factors threatening the green areas are the expansion of construction in urban areas - specifically housing projects - as well as poor urban planning.

Globally, previous research conducted has focused more on estimating the economic benefits of improving air quality, rather than quantitatively evaluating the effect of urban vegetation on ambient pollutant concentrations [74-79]. As for GC, previous studies tackling the issue in $\mathrm{GC}$ have not been the focus of researchers. Environmental issues, such as those related to water and land resources, have had more attention from researchers as well as governmental and non-governmental organizations. Additionally, practical efforts for controlling air pollutants

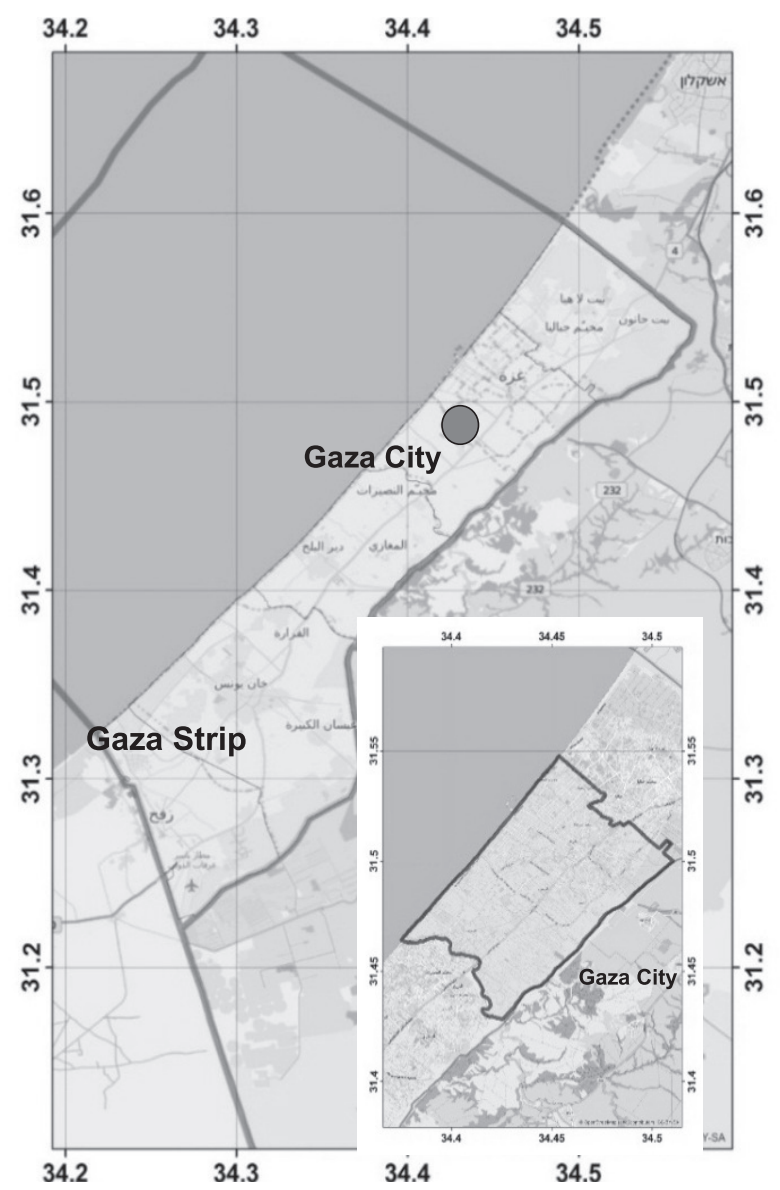

Fig. 1. Gaza Strip map (with Gaza City highlighted). 


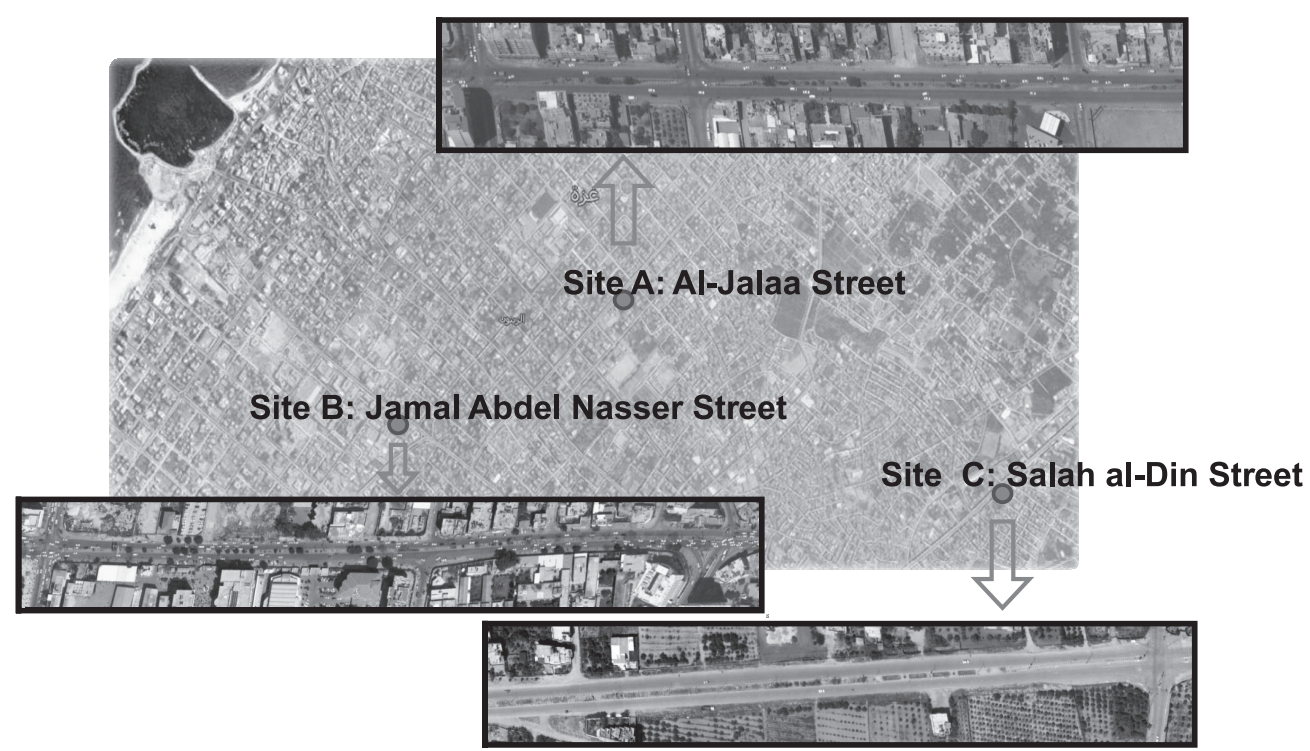

Fig. 2. Sampling sites for this study (sites where atmospheric $\mathrm{CO}_{2}$ concentration measurements took place).

and mitigating the challenge has been very limited. This may to some extent be due to the lack of monitoring stations and hence reliable data. Furthermore, the institutional incapacity to interpret data and take appropriate action is a key hindering factor toward improving air quality.

Hence this study provides quantitative information of atmospheric $\mathrm{CO}_{2}$ concentrations in three heavilytrafficked streets. Additionally, it examines the traffic count and the green cover percentage in all selected sites. Furthermore, it highlights the awareness and acceptance level of the local population toward greening their streets. Thus, this study can act as a guide for developing planning and conservation policies on both local and national levels. Moreover, it establishes a basis for other studies

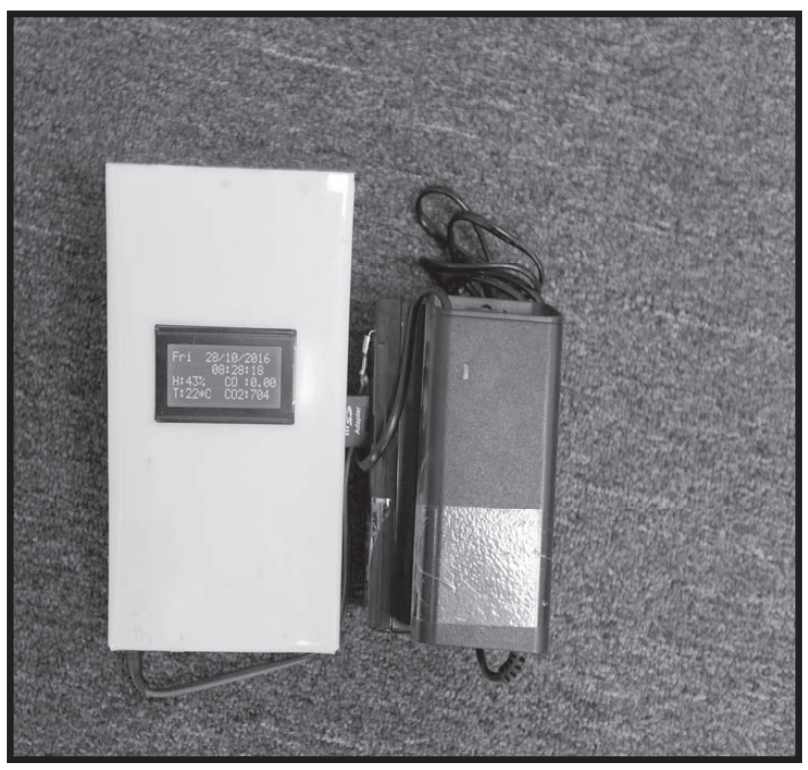

Fig. 3. Locally manufactured and calibrated air quality measuring device (designed and manufactured specifically for this study). in the same field and provides recommendations for all interested parties, including governmental and nongovernmental organizations.

\section{Materials and Methods}

A descriptive and analytical approach has been used for the purpose of this study. Field measurements for quantifying atmospheric $\mathrm{CO}_{2}$ concentration have been carried out in three main and heavily-trafficked streets in GC. Measurements have been taken in three different spots along each street over a two-day period (weekday and weekend) and at the following specific times:

- 08:00 (morning period/rush hour).

- 12:00 (midday period/rush hour).

- 18:00 (evening period).

Researchers have also made use of secondary data published in books, magazines, and periodicals.

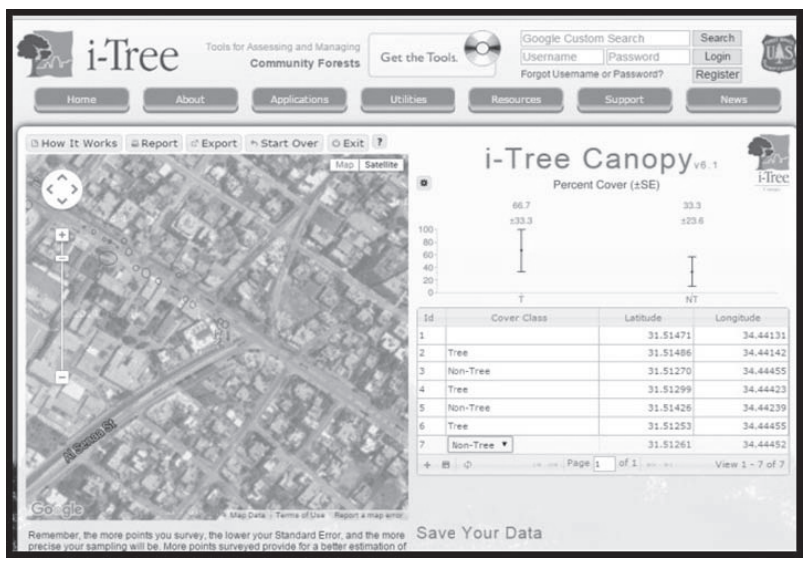

Fig. 4. Screenshot of I-Tree Canopy cover survey. Source: itreetools.org/canopy/survey.php 02/12/2015 


\section{Site Selection and Description}

Sections with an approximate length of $300 \mathrm{~m}$ within three heavily trafficked urban streets in GC were selected for atmospheric $\mathrm{CO}_{2}$ concentration measurements. All selected sections have the following in common (specifically considered aspects for study purposes):

- Two-way streets with buildings flanked on both sides (urban canyons), but with different width-to-height ratios.

- Uniform geometric characteristics along the section length and located between two junctions.

- Uninterrupted traffic flow.

- Very little pedestrian and/or animal traffic.

Streets within which sections are selected are illustrated in Fig. 2 and are as follows:

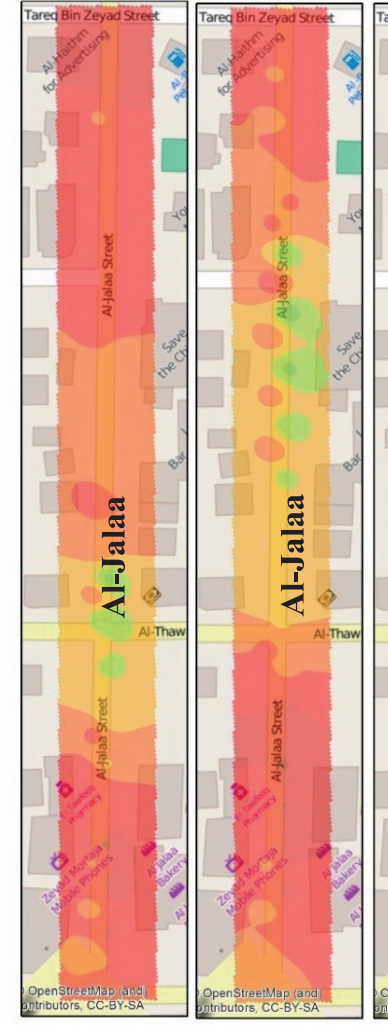

a) 08:00 b)

12:00

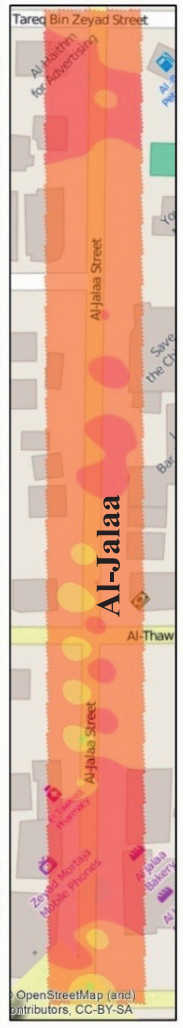

c)
- Al-Jalaa Street (site X): a highway street in the GC with six lanes and that extends over $3.47 \mathrm{~km}$ and is $24 \mathrm{~m}$ wide.

- Jamal Abdel Nasser Street (site Y; alternatively known as Al-Thalatheeni Street): a main street in the GC that extends over $3.2 \mathrm{~km}$ and is $30 \mathrm{~m}$ wide. This street has a number of important facilities such as the UNRWA headquarters and the two major universities within the city (the Islamic University of Gaza and A-Azhar University).

- Salah al-Din Street (site Z; alternatively known as the Salah al-Din Highway): the main highway of the Gaza Strip and that extends over $45 \mathrm{~km}$. It spans the entire length of the territory from the Rafah Crossing (the border between the GS and Egypt) in the south to the Erez Crossing (a pedestrian/cargo terminal on

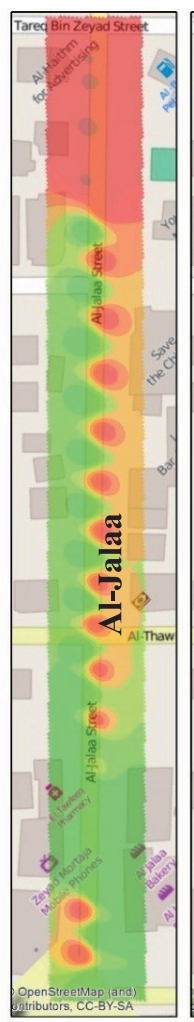

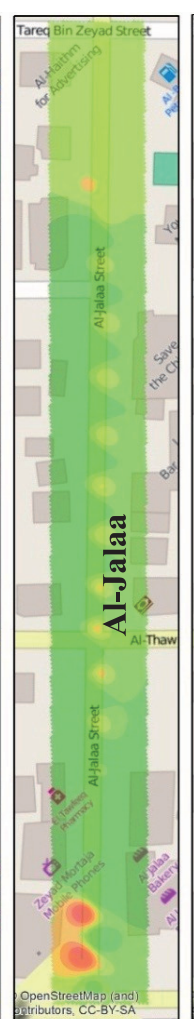

e)

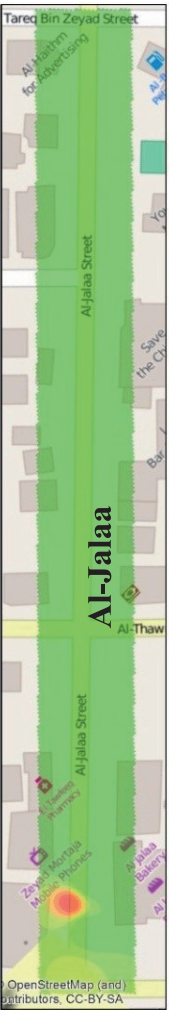

f) d)
18:00

\section{CO2 Concentration}

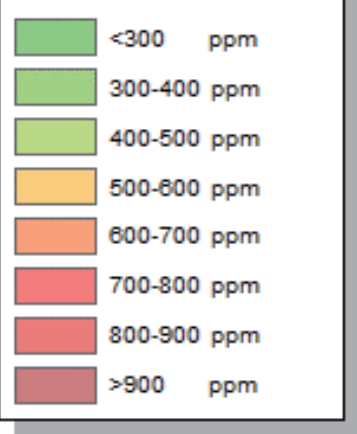

a) Working Day - Morning Period

b) Working Day - Midday Period

c) Working Day - Evening Period

d) Weekend - Morning Period

e) Weekend - Midday Period

f) Weekend - Evening Period

Fig. 5. Mapping measured and simulated atmospheric $\mathrm{CO}_{2}$ concentrations in site $\mathrm{X}$. 
the Israeli Gaza Strip barrier) in the north. The road is named after the $12^{\text {th }}$-century Muslim general Salah al-Din.

Note: sites selected will be referred to as sites X, Y, and Z in the order presented above.

\section{Traffic Count and Vehicle Classification}

Traffic-flow count was carried out manually through the visual assessment of vehicles. There are various classification approaches available to various institutions or end users. For the purposes of this study vehicles are classified into six categories:

- New privately owned cars.

- Used privately owned cars.

- Minibuses.
- Heavy buses.

- Heavy lorries (more than 10 and less than 20 tons).

- Motorcycles.

Traffic count was carried out at the same time the atmospheric $\mathrm{CO}_{2}$ concentration was measured. Time intervals were distributed as follows:

- 07:40-08:20 (morning period),

- 12:40-13:20 (midday period),

- 17:40-18:20 (evening period).

\section{$\mathrm{CO}_{2}$ Measuring Device Description}

A locally manufactured and calibrated air quality measuring device was designed and manufactured specifically for this study (see Fig. 3). It was calibrated using a state-of-the-art device from the Palestinian

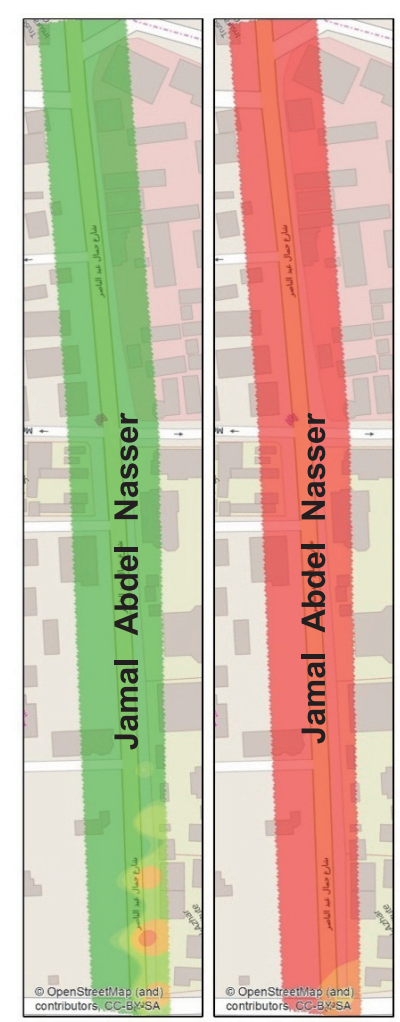

a)

08:00

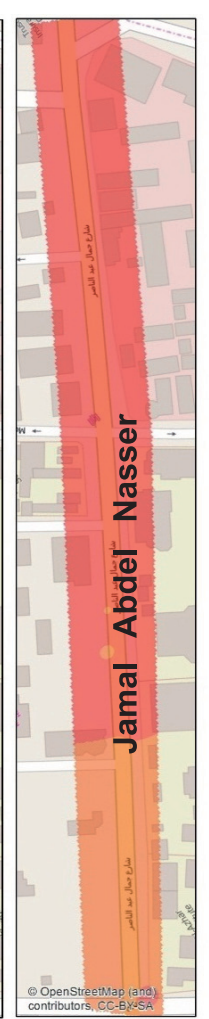

c)

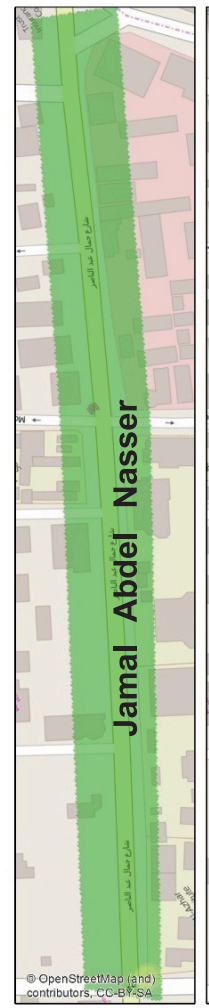

d)

08:00

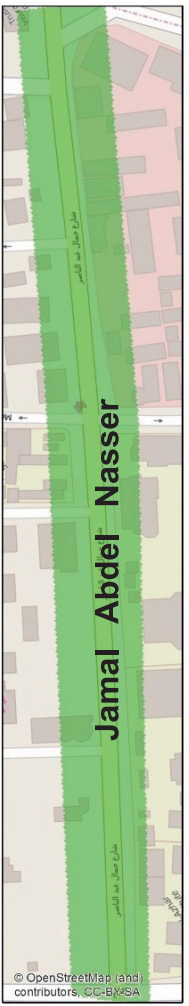

e)

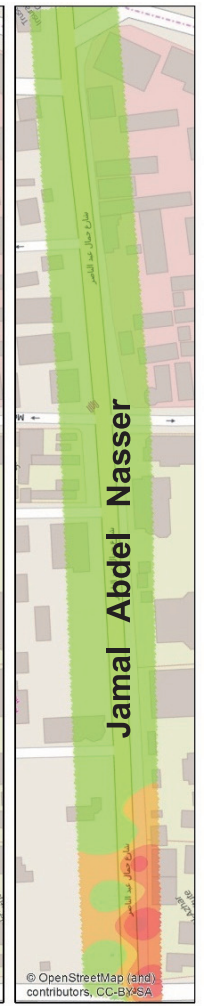

f)

18:00

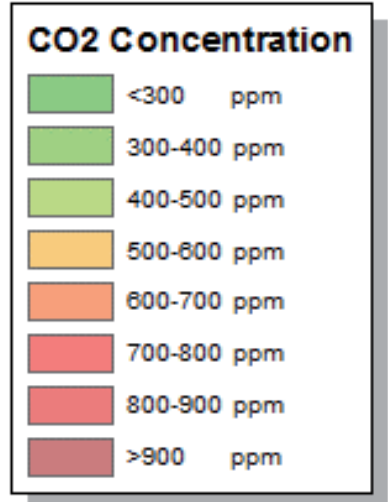

a) Working Day - Morning Period

b) Working Day - Midday Period

c) Working Day - Evening Period

d) Weekend - Morning Period

e) Weekend - Midday Period

f) Weekend - Evening Period

Fig. 6. Mapping measured and simulated atmospheric $\mathrm{CO}_{2}$ concentrations in site $\mathrm{Y}$. 


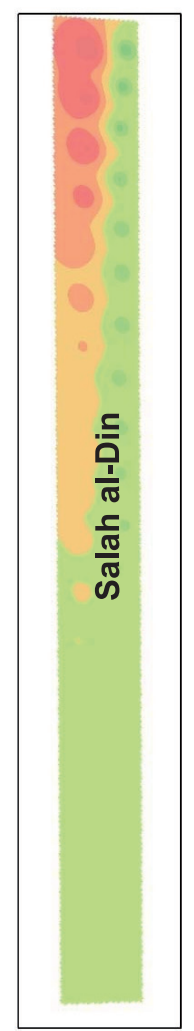

a)

08:00

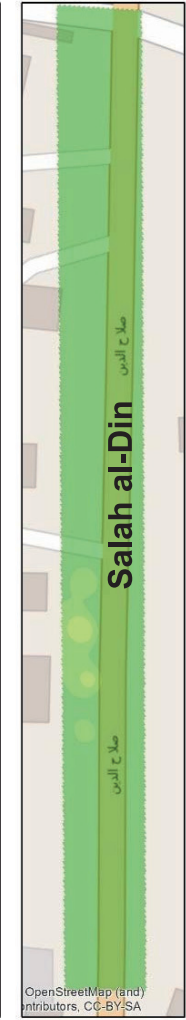

b)

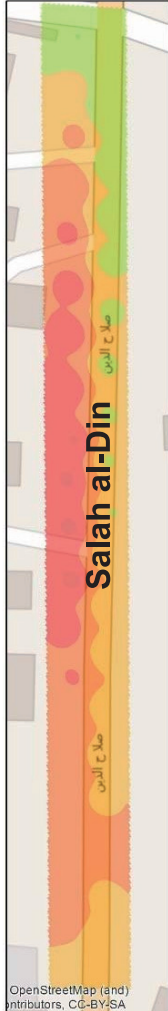

c)

18:00

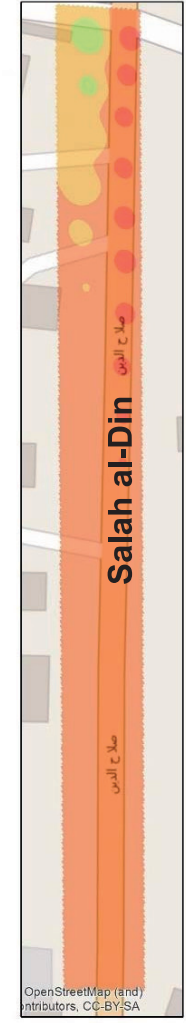

d)

08:00

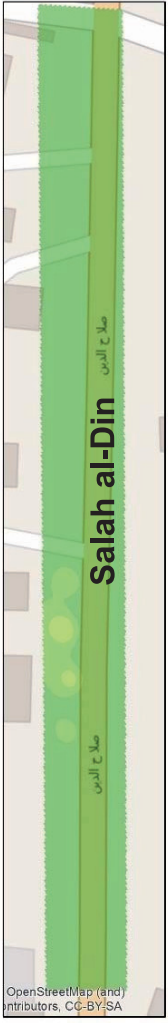

e)

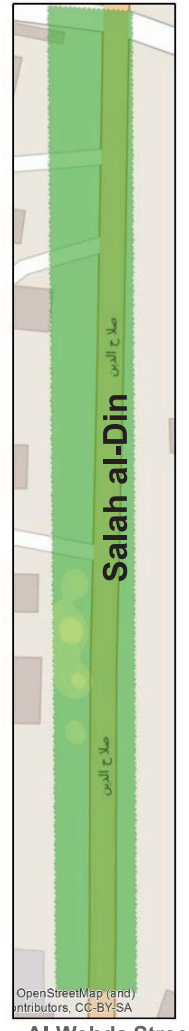

Al-Wehda Stree 18:00

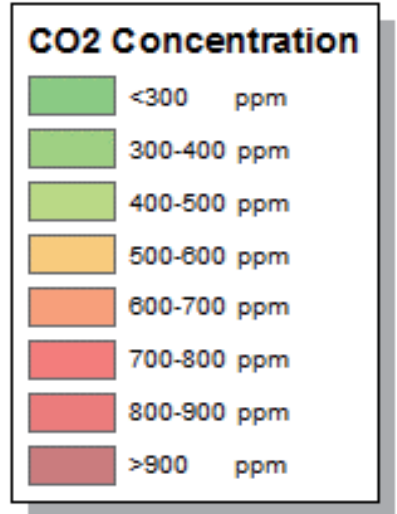

a) Working Day - Morning Period

b) Working Day - Midday Period

c) Worming Day - Evening Period

d) Weekend - Morning Period

e) Weekend - Midday Period

f) Weekend - Evening Period

Fig. 7. Mapping measured and simulated atmospheric $\mathrm{CO}_{2}$ concentrations in site $\mathrm{Z}$.

Environment Quality Authority (PEQA). The device can measure temperature, relative humidity, and $\mathrm{CO}_{2}$ based on a pre-defined time interval using different built-in sensors to collect surrounding air quality results. The collected data sets are stored automatically on an external USB stick and can be exported as a comma delimited file (CSV) for analysis and simulation purposes.

\section{Analysis of $\mathrm{CO}_{2}$ Field Measurements}

The CSV files for the field collected values from the selected sites were prepared and imported into GIS software (ArcMap10.2) for analysis and interpolation purposes. A total of 18 interpolation maps were generated for atmospheric $\mathrm{CO}_{2}$ concentration levels (six for each site). Three maps were generated for a typical working day and another three maps for a weekend day, for each selected site.

The interpolation technique was the inverse distance weight (IDW) approach. This technique uses a set of data points with coordinates $\mathrm{x}$ and $\mathrm{y}$, while the $\mathrm{z}$ values include the atmospheric $\mathrm{CO}_{2}$ concentration. With a predetermined working area (the extents of each site), the tool generates the required values covering the entire targeted area. A predefined colored map legend indicates the acceptable and non-acceptable levels of atmospheric $\mathrm{CO}_{2}$ concentrations in parts per million (ppm). The green grades indicate acceptable levels while the red grades indicate nonacceptable levels, and the cutting edge between the two levels is $300 \mathrm{ppm}$. 


\section{Urban Tree Inventory}

Urban vegetation within the study area was surveyed in order to assess its impact on atmospheric $\mathrm{CO}_{2}$ concentrations in all selected streets. A survey was conducted using the top-down approach. Photo interpretation using aerial-satellite images was carried out to determine the amount and distribution of the green cover. This process produces statistical estimates of cover. Accuracy of such estimates is highly dependent on the number of points considered (a sample of 100 points will produce an estimate with a standard error of about $4.6 \%$ compared to $1.4 \%$ for a sample of 1,000 points). For the purpose of this study a sample of 40 points was interpreted (collected from the field data). I-tree canopy was used to estimate land cover types using shapefile based on the available aerial photos. I-tree canopy is an online freely available tool that produces a statistically valid estimate of land cover types (e.g., tree cover) using aerial images available in Google Maps. The shapefile contains the feature of the sites including the green cover, streets, sides of the roads, and other features (see Fig. 4).

\section{Questionnaire Design}

Two sets of questionnaires were developed in order to assess pedestrians and shop owner air quality problem awareness. Additionally, it tested the respondents' level of acceptance toward greening the city. Both questionnaires were designed to collect qualitative data of the following aspects:

- Personal Information.

- Environmental Awareness (including source of pollution, nature of the place, interaction with circumstances, and awareness of climate change).

- Preferences of pedestrians and property owners.

The sample size for the questionnaire was determined using Eq. (1) (Saunders, 2012):

$$
N=\frac{N P}{1+\left(N P \times e^{2}\right)}
$$

...where $\mathrm{N}$ is sample size, NP is population size, and e is the errors term $=0.05$.

\section{Results}

\section{Measured and Simulated Atmospheric $\mathrm{CO}_{2}$ Concentrations in the Selected Sites}

The lowest atmospheric $\mathrm{CO}_{2}$ concentration was $10 \mathrm{ppm}$ (which is the lowest limit the device can detect), while the highest atmospheric $\mathrm{CO}_{2}$ concentration was 999 ppm (which is the highest limit the device can detect). A mapping of measured and simulated atmospheric $\mathrm{CO}_{2}$ concentrations in the three selected sites is illustrated in Figs 5-7.

\section{Working Day Measurements}

At site $\mathrm{X}$, atmospheric $\mathrm{CO}_{2}$ concentrations ranged between $500 \mathrm{ppm}$ and $900 \mathrm{ppm}$ at all measuring times. Whereas at site $\mathrm{Y}$, the latter measured was lowest in the morning, measuring $<300 \mathrm{ppm}$, followed by $>600$ $\mathrm{ppm}$ in the evening and $>800 \mathrm{ppm}$ in the afternoon. At site $\mathrm{Z}$, atmospheric $\mathrm{CO}_{2}$ concentration was lowest in the afternoon, measuring $<300 \mathrm{ppm}$ and highest in the evening, ranging between $500 \mathrm{ppm}$ and $900 \mathrm{ppm}$. Whereas in the morning, it ranged between $300 \mathrm{ppm}$ and $600 \mathrm{ppm}$.

\section{Weekend Measurements}

At site $\mathrm{X}$, atmospheric $\mathrm{CO}_{2}$ concentration was highest in the morning, ranging between $300 \mathrm{ppm}$ and $900 \mathrm{ppm}$. In the afternoon and evening it measured $<300 \mathrm{ppm}$. At site $\mathrm{Y}$, the latter mentioned was comparatively low at all measuring times - measuring $<400 \mathrm{ppm}$ in the morning and afternoon and $<300$ in the evening. In site $\mathrm{Z}$, atmospheric $\mathrm{CO}_{2}$ concentrations were highest in the morning, ranging between $600 \mathrm{ppm}$ and $900 \mathrm{ppm}$, whereas the lowest levels were detected in the afternoon all measuring $<300 \mathrm{ppm}$.

\section{Traffic-flow Count}

Fig. 8 illustrates the Traffic flow count for the three selected sites during a working day and a weekend.

\section{Urban Tree Canopy Assessment}

Fig. 9 illustrates the tree cover to non-tree cover percentage. Tree cover was $2 \%, 3 \%$, and $8 \%$ in sites $\mathrm{X}, \mathrm{Y}$, and $Z$, respectively.

\section{Local Population Awareness and Level of Acceptance Toward Greening their Streets}

\section{Demographic Profile of Respondents (Pedestrians and Shop-Owners)}

As shown in Table 1, the age group 21-30 years accounted for the largest percentage followed by the age group $<20$ among pedestrians. Females represented slightly more than $50 \%$ of the sample. The majority of pedestrian respondents were bachelor degree holders. As for marital status, the majority were single. Furthermore, the monthly salaries were between $\$ 0-500$ for about two third of the sample.

From shop-owners respondents' point of view, the age groups 21-30 years accounted for the largest percentages, followed by the age group 41-50. The majority were males, representing $99 \%$ of the sample. Furthermore, the 


\section{Traffic Flow Count During a Working Day}

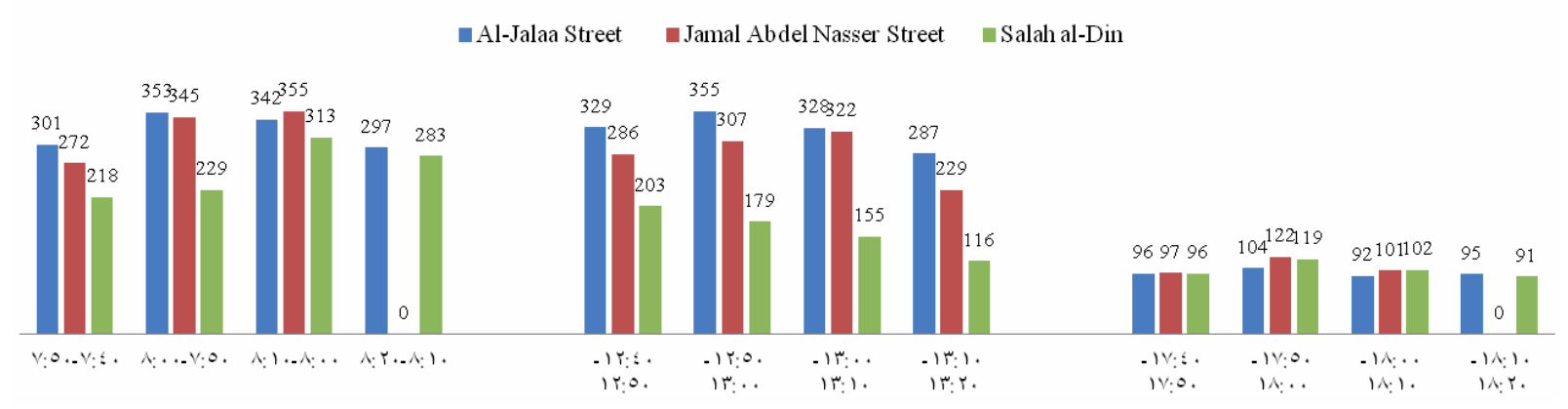

Traffic Count Flow During a Weekend

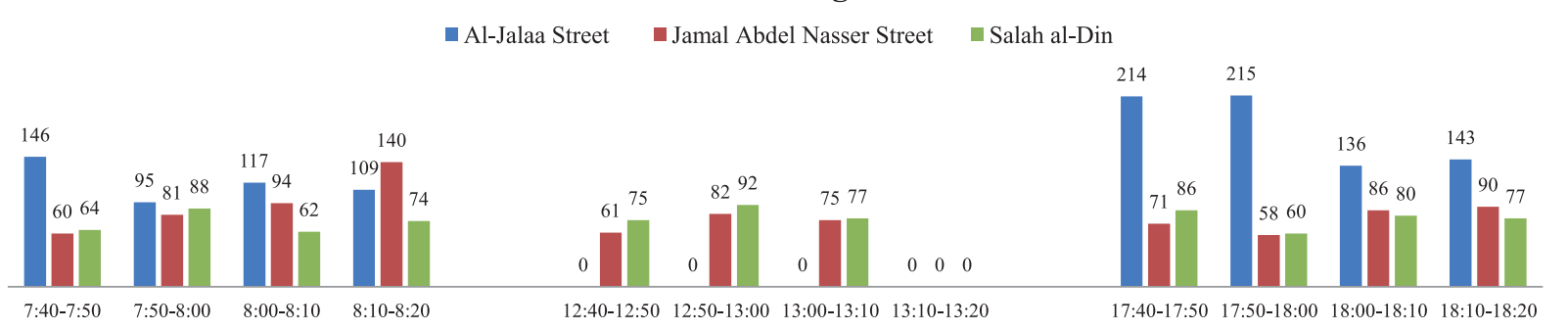

Fig. 8. Traffic flow count for the three selected sites during a working day and a weekend.

majority of shop-owners respondents' were high school graduates or lower. Furthermore, the monthly salaries were between $\$ 0-500$, representing about two third of the sample.

\section{Environmental Awareness of Respondents}

In general, Table 2 demonstrates that the MVs were relatively high at around 4.00 from respondents' (both pedestrians and shop-owners) point of view. The total mean values (MVs) scored 3.97 and 3.99, and the standard deviation values (SDs) scored 0.468 and 0.678 for pedestrians and shop-owners, respectively.

\section{Respondents'Preferences}

In general, Table 3 demonstrates that the MVs were relatively high at around 4.00 from respondants' (both pedestrians and shop-owners) point of view. The Total MV generally scored 4.13 and 4.23 and the total SD

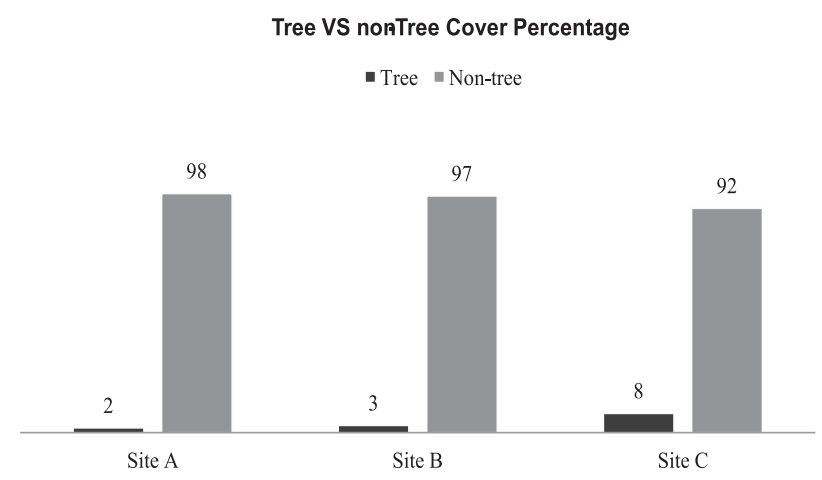

Fig. 9. Tree to non-tree cover percentage in the selected sites. scored 0.489 and 0.549 for pedestrians and shop-owners, respectively.

\section{Poor Air Quality Causes from Respondents' Point of View}

Table 4 shows that all respondents (pedestrians and shop-owners) ranked the high number of transportation means as the major cause for air pollution. Furthermore, the pedestrians ranked the lack of well-managed traffic as the second cause, whereas shop-owners believed that the lack of green spaces is the second cause. Finally, the lowest item ranked is the lack of pedestrian areas and the spread of sandy plots by pedestrians and shop-owners, respectively.

\section{Discussion}

Generally, higher atmospheric $\mathrm{CO}_{2}$ concentration was detected during the working day in all three selected sites, compared to that detected during the weekend. This can basically be attributed to the increased traffic volume encountered during working days. Furthermore, variations have been noticed within the same site during the different measuring times in both the working day and the weekend.

For instance, at site $\mathrm{X}$ higher atmospheric $\mathrm{CO}_{2}$ concentration has been detected during the working day at all measuring times - compared to that at the weekend. This typically can be attributed to the increased traffic volume during the working day. Little variation was detected between the three measuring times within the same working day; even though lower traffic volume was noticed during the evening period. Little variation was 
Table 1. Respondent profiles (pedestrians and shop-owners).

\begin{tabular}{|c|c|c|c|c|c|}
\hline \multirow{2}{*}{ Variable } & \multirow{2}{*}{ Interval } & \multicolumn{2}{|c|}{ Pedestrians } & \multicolumn{2}{|c|}{ Shop-owners } \\
\hline & & Frequency & Percentage & Frequency & Percentage \\
\hline \multirow{5}{*}{ Age } & 20 years or fewer & 117 & 29.3 & 1 & 17 \\
\hline & $21-30$ years & 181 & 45.3 & 49 & 49 \\
\hline & $31-40$ years & 67 & 16.8 & 11 & 11 \\
\hline & $41-50$ years & 23 & 5.8 & 14 & 14 \\
\hline & 51 years and above & 12 & 3 & 9 & 9 \\
\hline \multirow{2}{*}{ Gender } & Male & 198 & 49.5 & 99 & 99 \\
\hline & Female & 202 & 50.5 & 1 & 1 \\
\hline \multirow{5}{*}{ Education level } & High school or lower & 81 & 20.3 & 47 & 47 \\
\hline & Diploma & 119 & 29.8 & 19 & 19 \\
\hline & Bachelor's & 172 & 43 & 32 & 32 \\
\hline & Master's & 17 & 4.3 & 1 & 1 \\
\hline & Ph.D. & 11 & 2.8 & 1 & 1 \\
\hline \multirow{4}{*}{ Marital status } & Single & 240 & 60 & 41 & 41 \\
\hline & Married & 141 & 35.3 & 54 & 54 \\
\hline & Widowed & 7 & 1.8 & 2 & 2 \\
\hline & Divorced & 12 & 3 & 3 & 3 \\
\hline \multirow{5}{*}{ Monthly salary } & $\$ 0-500$ & 283 & 70.8 & 66 & 66 \\
\hline & $501-1,000$ & 61 & 15.3 & 25 & 25 \\
\hline & $\$ 1,001-1,500$ & 40 & 10 & 7 & 7 \\
\hline & $\$ 1,501-2,000$ & 7 & 1.8 & 1 & 1 \\
\hline & More than $\$ 2,000$ & 9 & 2.3 & 1 & 1 \\
\hline \multirow{5}{*}{$\begin{array}{l}\text { Years of } \\
\text { Experience }\end{array}$} & 5 years or less & 285 & 71.3 & 5 & 5 \\
\hline & $6-10$ years & 69 & 17.3 & 24 & 24 \\
\hline & $11-15$ years & 28 & 7 & 13 & 13 \\
\hline & $16-20$ years & 16 & 4 & 8 & 8 \\
\hline & 21 years and above & 2 & 0.5 & 5 & 5 \\
\hline \multirow{2}{*}{ Nature of the job } & Related to environment & $-^{a}$ & - & 58 & 58 \\
\hline & Non-related to environment & - & - & 42 & 42 \\
\hline
\end{tabular}

${ }^{a}$ The dash mark in the table means that the respondent's point of view was not considered for this specific aspect

also detected between the three measuring times within the same weekend, even though traffic volume was highest in the evening period.

At site $\mathrm{Y}$, higher atmospheric $\mathrm{CO}_{2}$ concentration was detected in the afternoon and evening compared to that detected in the morning during the working day, even though traffic volume in the evening was the lowest. During the weekend lower atmospheric $\mathrm{CO}_{2}$ concentration was detected at all measuring times with little variation. This can be attributed to reduced traffic volume during the weekend, which happens to be almost consistent at all measuring times.
In sites $\mathrm{X}$ and $\mathrm{Y}$, higher atmospheric $\mathrm{CO}_{2}$ concentrations were measured during times when low traffic volume was detected and can be strongly attributed to other sources that were not considered within the scope of this study (e.g., small-scale generators used to compensate for power cut-offs).

On the contrary at site $\mathrm{Z}$, the highest atmospheric $\mathrm{CO}_{2}$ concentration was detected in the evening, even though traffic volume was highest in the morning. During the weekend, higher atmospheric $\mathrm{CO}_{2}$ concentration was detected in the morning even though traffic volume was consistent at all measuring times. 
Table 2. Environmental awareness of respondents.

\begin{tabular}{|c|c|c|c|c|}
\hline \multirow{2}{*}{ Item } & \multicolumn{2}{|c|}{ Pedestrians } & \multicolumn{2}{|c|}{ Shop-owners } \\
\hline & MV & SD & MV & SD \\
\hline \multicolumn{5}{|l|}{ Pollution Source } \\
\hline Vehicle exhaust gases affect air quality & 4.66 & 0.702 & 4.64 & 0.789 \\
\hline Small power generators in the streets affect air quality & 4.02 & 0.954 & 4.56 & 0.743 \\
\hline The dust on the street sides affect air quality & 4.04 & 0.855 & 4.15 & 0.957 \\
\hline Other pollution sources (for example barbeque shops, car workshops, ...) affect air quality & 4.00 & 0.929 & 4.03 & 0.893 \\
\hline Total of pollution source & 4.18 & 0.508 & 4.35 & 0.566 \\
\hline \multicolumn{5}{|l|}{ Nature of place } \\
\hline Lack of green spaces affects air quality & 4.20 & 1.040 & 4.28 & 0.900 \\
\hline Lack of public spaces (pedestrian spaces) affects air quality & 3.75 & 1.157 & 3.91 & 1.065 \\
\hline Planting trees at the expense of public spaces quality is essential to improve air quality & 4.09 & 1.008 & 3.97 & 1.058 \\
\hline Lack of planning regulations for buildings affects air quality & 3.78 & 1.009 & 4.19 & 0.837 \\
\hline Street width and direction affect air quality & 3.85 & 0.992 & 4.02 & 0.964 \\
\hline Total of nature of place & 3.92 & 0.582 & 4.07 & 0.675 \\
\hline \multicolumn{5}{|l|}{ Interaction of community } \\
\hline I try to avoid walking in crowded areas due to bad air quality & 4.13 & 0.977 & 4.09 & 1.016 \\
\hline I intend to comply with construction regulations to contribute toward good air quality practices & 3.81 & 1.037 & - & - \\
\hline $\begin{array}{l}\text { The non-compliance of house owners to proper construction regulations (e.g., not leaving } \\
\text { appropriate spaces between structures) affects air quality }\end{array}$ & - & - & 4.02 & 1.063 \\
\hline I have sound knowledge of regulations related to air quality & 3.51 & 1.112 & 3.54 & 1.218 \\
\hline Fines should be issued against non-compliance house-owners related to air quality & 3.80 & 1.053 & 4.06 & 0.908 \\
\hline $\begin{array}{l}\text { I am willing to comply with the urban greening regulations issued by local specialized } \\
\text { institutions }\end{array}$ & 4.00 & 1.114 & 4.05 & 1.068 \\
\hline Total of interaction of community & 3.86 & 0.669 & 3.95 & 0.787 \\
\hline \multicolumn{5}{|l|}{ Climate change awareness } \\
\hline I have sound knowledge about climate change concepts & 3.99 & 1.028 & 3.47 & 1.201 \\
\hline Air quality is related to climate change & 3.96 & 0.949 & 3.72 & 1.045 \\
\hline Total of climate change awareness & 3.97 & 0.768 & 3.60 & 1.036 \\
\hline Average of environmental awareness results & 3.97 & 0.468 & 3.99 & 0.678 \\
\hline
\end{tabular}

This can be attributed to $\mathrm{CO}_{2}$ emitted from industrial workshops flanked on both sides of the street (found only in Site Z).

The urban vegetation cover for the selected sites was estimated at $2 \%, 3 \%$, and $8 \%$ in sites $\mathrm{X}, \mathrm{Y}$, and $\mathrm{Z}$, respectively. However, the lowest atmospheric $\mathrm{CO}_{2}$ concentration was detected in site $\mathrm{Y}$, followed by site $\mathrm{Z}$, and the highest was found at site $\mathrm{X}$. Higher atmospheric $\mathrm{CO}_{2}$ concentration at site $\mathrm{Y}$ can be attributed to $\mathrm{CO}_{2}$ emitted by industrial workshops flanking both sides of the street. As for site $\mathrm{X}$, reduced urban vegetation cover might have contributed to higher atmospheric $\mathrm{CO}_{2}$ concentrations.

The questionnaire results revealed a decent level of air quality problem awarness among both pedestrians and shop-owners. Furthermore, it illustrated a general tendency and willingness among respondents toward applying actions to reduce and control air pollution. These actions include complying with any regulations enforced by relevant governmental institutions and local municipalities. Additionally, the analysis revealed that respondents are willing to use any available environmentally friendly technologies that would reduce $\mathrm{CO}_{2}$ emissions. It also demonstrated that respondents believe that relevant governmental institutions should play the required role in regulating air quality control procedures.

As for poor air quality causes, the highest item ranked among respondents was the high number of cars followed by the lack of well-managed traffic and finally the lack 
Table 3. Respondents' preferences for actions to be enforced by local muncipilities regarding enhancing air quality.

\begin{tabular}{|c|c|c|c|c|}
\hline \multirow{2}{*}{ Item } & \multicolumn{2}{|c|}{ Pedestrians } & \multicolumn{2}{|c|}{ Shop-owners } \\
\hline & MV & $\mathrm{SD}$ & MV & SD \\
\hline $\begin{array}{l}\text { Local municipalities should enforce property construction regulations that affect air } \\
\text { quality. }\end{array}$ & 4.36 & 0.81 & 4.23 & 0.723 \\
\hline $\begin{array}{l}\text { Relevant governmental institutions and local municipalities should perform awareness } \\
\text { campaigns regarding relevant air quality regulations. }\end{array}$ & 4.10 & 0.965 & 4.42 & 0.741 \\
\hline I have the will to volunteer and participate in air quality awareness campaigns. & 4.01 & 0.942 & 3.90 & 1.049 \\
\hline $\begin{array}{l}\text { Relevant governmental institutions should issue penalties for those who are not } \\
\text { complying with air quality regulations. }\end{array}$ & 3.96 & 0.99 & 4.24 & 0.866 \\
\hline $\begin{array}{l}\text { Subsidized community-encouraging projects should be performed related to air } \\
\text { quality improvement. }\end{array}$ & 4.36 & 0.80 & 4.26 & 0.883 \\
\hline $\begin{array}{l}\text { I have the will to use environmentally friendly technologies (e.g., solar panels, low } \\
\text { emission vehicles) available in the market to reduce air pollution. }\end{array}$ & 4.26 & 0.88 & 4.29 & 0.998 \\
\hline $\begin{array}{c}\text { Shop owners should provide required spaces for implementing air pollution } \\
\text { enhancement projects within their own properties. }\end{array}$ & - & - & 4.21 & 0.88 \\
\hline $\begin{array}{l}\text { The relevant governmental institutions (ministry of transportation) should enforce } \\
\text { traffic reduction strategies, especially at traffic nodes. }\end{array}$ & 3.85 & 0.955 & 4.13 & 0.939 \\
\hline $\begin{array}{l}\text { The relevant governmental institutions (EQA) should increase green areas in heavily } \\
\text { trafficked, densely polluted areas. }\end{array}$ & 4.19 & 0.852 & 4.43 & 0.795 \\
\hline Average of pedestrians and shop-owners preferences & 4.13 & 0.389 & 4.23 & 0.549 \\
\hline
\end{tabular}

Table 4. Respondents' perception of poor air quality causes.

\begin{tabular}{|c|c|c|c|c|}
\hline \multirow{2}{*}{ Item } & \multicolumn{2}{|c|}{ Pedestrians } & \multicolumn{2}{|c|}{ Shop-owners } \\
\hline & Frequency & $\%$ & Frequency & $\%$ \\
\hline High numbers of transportation means & 161 & 40.3 & 58 & 58 \\
\hline Lack of well-managed traffic (traffic congestion) & 43 & 10.8 & 4 & 4 \\
\hline Lack of green spaces (public gardens) & 35 & 8.8 & 10 & 10 \\
\hline Lack of pedestrian areas (middle and sides of streets) & 7 & 1.8 & 2 & 2 \\
\hline $\begin{array}{l}\text { Repeated Israeli intrusions and attacks on public infrastructure in } \\
\text { the Gaza Strip }\end{array}$ & 78 & 19.5 & 11 & 11 \\
\hline The spread of sandy un-urbanized plots (non-fenced plots) & 22 & 5.5 & 2 & 2 \\
\hline The existence of many sandy (un-paved) roads & 21 & 5.3 & 1 & 1 \\
\hline The excessive use of power generators & 31 & 7.8 & 11 & 11 \\
\hline Other, please specify & 2 & 0.5 & 1 & 1 \\
\hline
\end{tabular}

of green space availability. This supports the findings from field observations and collected air quality data, as there was a high inter-correlation between the number of transportation means and the levels of atmospheric $\mathrm{CO}_{2}$ concentrations. There was also an inter-correlation between the levels of atmospheric $\mathrm{CO}_{2}$ concentration and the urban vegetation cover percentage.

\section{Conclusions}

The findings presented in the study suggest that transportation means is the first major source of $\mathrm{CO}_{2}$ in the study area. An inter-correlation was found between the levels of atmospheric $\mathrm{CO}_{2}$ concentration and the urban vegetation cover percentage. Lower atmospheric $\mathrm{CO}_{2}$ concentration was detected in areas with increased green cover (except for site Z). However, in the latter-mentioned site, industrial workshops flanking both sides of the street may have strongly contributed to increased levels of atmospheric $\mathrm{CO}_{2}$ concentrations.

Furthermore, the questionnaire analysis supported the findings from field observations and collected air quality data. Respondents (pedestrian and shop-owners) illustrated a general tendency toward applying actions and fullfilling any air quality control regulations to control air pollution with a relatively high mean value of around 4.00 . 
It would be fruitful to pursue further research to quantitatively estimate carbon sequestration by urban street trees using tree volume and biomass allometric equations. This will aid in specifying the type, location, and number of trees to be planted in urban street canyons. Furthermore, quantitatively evaluating other main pollutants (particulate matter, nitrogen oxide, and groundlevel ozone) will facilitate identifying other possible mitigation measures.

If policymakers were to take this study seriously, they might issue and/or enforce regulations regarding traffic-management to reduce $\mathrm{CO}_{2}$ emissions and hence enhance air quality. Additionally, they might issue policies regarding increasing the green cover, especially in heavily trafficked street canyons.

\section{Acknowledgements}

This study was supported by the Fund for Supporting Palestinian Universities (hosted by the University of Jordan). The views expressed in this article are those of the authors and do not necessarily reflect the views or policies of the funding institution.

Mohammed Salem would like to thank Avempace III, Erasmus Mundus and the University of Deusto for giving him a Post Doc scholarship, and thanks Mr. Nabil Sarraf for his continuous support.

\section{References}

1. WORLD HEALTH ORGANIZATION (WHO). Health and Environment Linkages Initiative (HELI). 2015. Retrieved from http://www.who.int/heli/en/

2. WORLD HEALTH ORGANIZATION (WHO). Ambient (outdoor) air quality and health, Fact sheet No. 313. 2014. Retrieved from http://www.who.int/mediacentre/factsheets/ fs $313 /$ en

3. WORLD HEALTH ORGANIZATION (WHO). Health in the Green Economy: Health co-benefits of climate change mitigation - Transport sector. Geneva. 2011. Retrieved from http://www.who.int/hia/examples/trspt_comms/hge_ transport lowresdurban 30 11_2011.pdf

4. HEALTH EFFECTS INSTITUTE (HEI). Traffic-related air pollution: A critical review of the literature on emissions, exposure, and health effects. Special Report 17. 2010. Retrieved from http://pubs.healtheffects.org/getfile. php? $\mathrm{u}=553$

5. WEISSERT L.F., SALMOND J.A., SCHWENDENMA L. A Review of the Current Progress in Quantifying the Potential of Urban Forests to Mitigate Urban $\mathrm{CO}_{2}$ Emissions. Urban Climate, 8, 100, 2014.

6. OECD. "Urbanisation and Green Growth in China", Regional Development Working Papers, 2013/07, OECD Publishing. 2013. http://dx.doi.org/10.1787/5k49dv68n7jfen.

7. KOCKELMAN K., BOMBERG M., THOMPSON M., WHITEHEAD C. GHG Emissions Control Options Opportunities for Conservation. Special report 298: driving and the 29 built environment: the effects of compact development on motorized travel, energy use, and $\mathrm{CO}_{2}$ emissions. The University of Texas, Austin. 2009. Retrieved from http://onlinepubs.trb.org/Onlinepubs/sr/ sr298kockelman.pdf

8. The Intergovernmental Panel on Climate Change (IPCC). Climate Change 2007: The Physical Science Basis: Trends in the Hydroxyl Free Radical. Contribution of Working Group I to the Fourth Assessment Report of the Intergovernmental Panel on Climate Change. 2007. Retrieved from https:// www.ipcc.ch/publications and data/ar4/wg1/en/ch2s2-3-5. html

9. WORLD ECONOMIC FORUM (WEF). Rising Pollution in the Developed World. 2015. Retrieved from http://reports. weforum.org/outlook-global-agenda-2015/top-10-trends-of2015/6-rising-pollution-in-the-developing-world/

10. WALKER G., FAIRBURN J., SMITH J., GORDON M. Environmental Quality and Social Deprivation. R\&D Technical Report E2-067/1/TR. 2003. Retrieved from https:// www.academia.edu/16820260/Environmental_quality_and social_deprivation

11. DODMAN D. United Nations Population Fund (UNFPA): Analytical Review of the Interaction between, Urban Growth Trends and Environmental Changes: Urban Density and Climate Change. 2009

12. GATELY C., HUTYRA L., WING S. Cities, traffic, and $\mathrm{CO}_{2}$ : A multidecadal assessment of trends, drivers, and scaling relationships. Paper presented at the Proceedings of the National Academy of Sciences of the United States of America. 112 (16), 2015.

13. CENTERS FOR DISEASES CONTROL AND PREVENTION (CDCP). Carbon Monoxide Hazards from Small Gasoline Powered Engines. 2012. http://www.cdc. gov/niosh/topics/co/ (Accessed: 21/07/2015).

14. NATIONAL RESEARCH COUNCIL (NRC). Advancing the Science of Climate Change. The National Academy of Sciences. 2010. Retrieved from http://dels.nas.edu/ resources/static-assets/materials-based-on-reports/reportsin-brief/Science-Report-Brief-final.pdf

15. DUREN R., MILLER C. Measuring the carbon emissions of megacities. Nat. Clim. Chang., 2, 560, 2012.

16. KARAVALAKIS G., STOUTNAS S., BAKEAS E. Light Vehicle Regulated and Unregulated Emissions from Different Biodiesels. Sci. Total Environ., 407 (10), 3338, 2009.

17. HILL J., NELSONE., TILMAN D., POLASKY S., TIFFANY D. Environmental, Economic, and Energetic Costs and Benefits of Biodiesel and Ethanol Biofuels. Paper presented at the Proceedings of the National Academy of Sciences of the United States of America. U.S., 25 July 2006. 103 (30), 11206, 2006. Retrieved from http://derechoalaalimentacion. org/wp-content/uploads/2012/08/Hill-Environmental-costsof-biofuels.pdf

18. PATAKI D.E., ALIG R.J., FUNG A.S., GOLUBIEWSKI N.E., KENNEDY C.A., MCPHERSON E.G., ROMEROLANKAO P. Urban Ecosystems and the North American Carbon Cycle. Glob. Chang. Biol., 12. 2092, 2006.

19. RAKOWSKA A., WONG K.C., TOWNSEND T., CHAN K.L., WESTERDAHL D., NG S., MOCNIK G., DRIOVEC L., NING Z. Impact of traffic volume and composition on the air quality and pedestrian exposure in urban street canyon. Atmos. Environ., 98, 260, 2014.

20. VACCARI F., GIOLI B.,TOSCANO P., PERRONEB C. Carbon Dioxide Balance Assessment of the City of Florence (Italy) and Implications for Urban Planning. Landscape and Urban Planning, 120, 138, 2013. Retrieved from http://www.sciencedirect.com/science/article/pii/ S0169204613001552 
21. WALSH M.P. Mobile Source Related Air Pollution: Effects on Health and the Environment. Reference Module in Earth Systems and Environmental Sciences. 803, 2013.

22. KAKOUEI A., VATANI A., BIN IDRIS A. An estimation of traffic related $\mathrm{CO}_{2}$ emissions from motor vehicles in the capital city of, Iran. J. environ. health sci. eng,. 9 (13), 2012.

23. EGGLESTON S., HACKMAN M.P., HEYES C.A., IRWIN J.G., TIMMIS R.J, WILLIAMS M.L. Trends in urban air pollution in the United Kingdom during recent decades. Atmos. Environ. Part B. Urban Atmosphere. 26 (2), 227, 1992.

24. FLORIDES G.A., CHRISTODOULIDES P. Global Warming and Carbon Dioxide Through Sciences. Environment International. 35 (2), 390, 2009.

25. THE INTERGOVERNMENTAL PANEL ON CLIMATE CHANGE (IPCC). Climate Change 2007: The Physical Science Basis: Trends in the Hydroxyl Free Radical Contribution of Working Group I to the Fourth Assessment Report of the Intergovernmental Panel on Climate Change. 2007. Retrieved from https://www.ipcc.ch/publications and data/ar4/wg1/en/ch2s2-3-5.html

26. MANN M., BRADLEY R.S., HUGHES M.K. Global-Scale Temperature Patterns and Climate Forcing Over the Past Six Centuries. Nature. 392, 779, 1998.

27. EL-DORGHAMY A. Fuel Economy and $\mathrm{CO}_{2}$ Emissions of Light-Duty Vehicles in Egypt. Centre for Environment and Development in the Arab Region and Europe (CEDARE). 2015. Retrieved from http://www.unep.org/ Transport/new/pcfv/pdf/GFEI_Egypt_Report_English.pdf

28. LITMAN T. Evaluating public transportation health benefits. Victoria Transport Policy Institute for The American Public Transportation Association. 2015. Retrieved from http://www.vtpi.org/tran health.pdf

29. DEUTSCHE BANK RESEARCH. $\mathrm{CO}_{2}$ Emissions from Cars: Regulation via EU Emissions Trading System better than stricter CO2 limits. 2014. Retrieved from https://www. dbresearch.com/PROD/DBR INTERNET EN-PROD/ PROD0000000000346332/CO $2+$ emissions + from + cars $\% 3$ $\mathrm{A}+$ Regulation+via+EU+Emissio.PDF

30. NEJADKOORKI F., NICHOLSON K., LAKE I., DAVIES T. An Approach for Modeling $\mathrm{CO}_{2}$ Emissions from Road Traffic in Urban Areas. Science of the Total Environment, 406, 1, 2008

31. MARCOTULLIO P.J., WILLIAMS E. Limited Provision of Roads as a Bottleneck on Vehicle $\mathrm{CO}_{2}$ Emissions in Asia: an International Comparison of National Trends. IJEP, 30 (1), 2007.

32. Audi. Motor Vehicle Exhaust Emissions: Composition, Emission Control, Standards, etc. Basics. 2006. Retrieved from http://www.volkspage.net/technik/ssp/ssp/SSP 230. pdf

33. METZ N. Contribution of Passenger Cars and Trucks to $\mathrm{CO}_{2}, \mathrm{CH}_{4}, \mathrm{~N}_{2} \mathrm{O}, \mathrm{CFC}$ and $\mathrm{HFC}$ Emissions. Paper presented at the Proceedings of the 2001 Environmental Sustainability Conference and Exhibition. Austria Graz. 353, 2001.

34. IMF. World Economic Outlook Database. International Monetary Fund. International Transport Forum: Key Transport. 2013. Retrieved from http://www.itf-oecd.org/ sites/default/files/docs/13keystat2012.pdf

35. US GEOLOGICAL SURVEY (USGS). Cement Statistics and Information, and other commodities. 2011, 2012, 2013 Retrieved from: http://minerals.usgs.gov/minerals/pubs/ commodity/
36. KOERNER B., KLOPATEK J. Anthropogenic and Natural $\mathrm{CO}_{2}$ Emission Sources in an Arid Urban Environment. Environ. Pollut., 116, 45, 2002.

37. INTERNATIONAL ENERGY AGENCY (IEA). $\mathrm{CO}_{2}$ emissions from fuel combustion. Paris. 2015. Retrieved from https://www.iea.org/publications/freepublications/ publication/CO2EmissionsFromFuelCombustionHighligh ts2015.pdf

38. ANDERSSON-SKÖLD Y., THORSSON S., RAYNER D., LINDBERG F., JANHÄLL S., JONSSON A.,MOBACK U., BERGMAN R., GRANBERG M. An integrated method for assessing climate related risks and adaptation alternatives in urban areas. Clim. Risk Manag., 7, 31, 2015.

39. JANHÄLL S. Review on urban vegetation and particle air pollution - Deposition and Dispersion. Atmos. Environ., 105, 130, 2015.

40. BUFFONI A., SILLI V., MANES F. Air Pollution Removal by Urban Green in Milan Town Centre Results from Model Estimations and Air Quality Measurements. 16 ${ }^{\text {th }}$ European Forum on Urban Forestry, Milano, Italy, 7-11 May, 2013.

41. LIU S., HITE D. Measuring the Effect of Green Space on Property Value: An Application of the Hedonic Spatial Quantile Regression. Annual Meeting, Orlando, Florida, 3-5 February, 2013.

42. AMERICAN RIVERS. Growing Green: How Green Infrastructure Can Improve Community Livability and Public Health, June, 2012. Retrieved from https://www. americanrivers.org/assets/pdfs/green-infrastructure-docs/ growing-green-how-green-infrastructure-can-improvecommunity-livability.pdf

43. HOSKING J., MUDU P., DORA C. World Health Organization (WHO). Health in the green economy: Cobenefits to health of climate change mitigation. 2011. Retrieved from $\mathrm{http}: / /$ extranet.who.int/iris/restricted/bitstre am/10665/70913/1/9789241502402917_eng.pdf

44. FOSTER J., LOWE A., WINKELMAN S. The Center for Clean Air Policy. The Value of Green Infrastructure for Urban Climate Adaptation. 2011.

45. KUTSCH W.L. in Old-Growth Forests: Function, Fate and Value (eds Wirth, C.,Gleixner, G. \& Heimann, M.). Springer, 57, 2009.

46. CATER M., Sustainable South Bronx. Urban Heat Island Mitigation Can Improve New York City's Environment: Research on the Impacts of Mitigation Strategies on the Urban Environment. Oct 2008. Retrieved fromhttp://www. deltacities.com/documents/NYC_SSBx_UHI_Mit_Can Improve_NYC_Enviro[1].pdf

47. NOWAK D., DANIEL C. Carbon Storage and Sequestration by Urban Trees in the USA. Environ. Pollut., 116 (2002), 381, 2001.

48. OMAYE S.T. "Metabolic Modulation of Carbon Monoxide Toxicity". Toxicology, 180 (2), 139, 2002.

49. BROWN S., SWINGLAND I., HANBURY-TENSION R., PRANCE G., MYERS N. Carbon sinks for abating climate change: can they work? Center for Environment and Society, University of Essex. 2001.

50. CAREY E.V., SALAA., KEANE R., CALLAWAY R.M. Are Old Forests Underestimated as Global Carbon Sinks? Glob. Chang. Biol, 7 (4), 339, 2001.

51. MCPHERSON E.G. Net Benefits of Healthy and Productive Urban Forests. In: Bradley, G., ed. Urban forest landscapes: integrating multi disciplinary perspectives. Seattle: University of Washington Press, 180, 1995.

52. MILLER R.H., MILLER R.W. Planting Survival of Selected Street Tree Taxa. Journal of Arboriculture, 17 (7), 185, 1991. 
53. STEPHENSON N.L., DAS A.J., CONDIT R., RUSSO S.E., BAKER P.J., LIN Y. Rate of Tree Carbon Accumulation Increases Continuously with Tree Size. Nature, 507, 2014.

54. MEINZER F.C., LACHENBRUCH B., DAWSON T.E. eds. Size- and Age-Related Changes in Tree Structure and Function. Springer, 2011.

55. PIPER F.I., FAJARDO A. No Evidence of Carbon Limitation with Tree Age and Height in Nothofaguspumilio Under Mediterranean and Temperate Climate Conditions. Ann. Bot., 108 (5), 907, 2011.

56. PHILLIPS N.G., BUCKLEY T.N., TISSUE D.T. Capacity of Old Trees to Respond to Environmental Change. JIPB , 50, 1355, 2008

57. WEINER J., THOMAS S.C. The Nature of Tree Growth and the "Age-Related Decline in Forest Productivity". Oikos, 94 (2), 374, 2001

58. MCALINEY M. Arguments for Land Conservation: Documentation and Information Sources for Land Resources Protection. Trust for Public Land, Sacramento, CA. 1993.

59. EUROPEAN COMMISSION (EC). Ambient Air Quality. 2016. Retrieved from http://ec.europa.eu/environment/air/ legis.htm

60. PALESTINIAN CENTRAL BUREAU STATISTICS (PCBS). 2016. Retrieved from http://www.pcbs.gov.ps/site/ lang en/881/default.aspx\#Population

61. PALESTINIAN CENTRAL BUREAU STATISTICS (PCBS). The Annual Report on Transportation and Communication Statistics in Palestine, 2012. 2013. Retrieved From http://www.pcbs.gov.ps/portals/_pcbs/ PressRelease/Press_En_PalTelTransNewE.pdf

62. PALESTINIAN CENTRAL BUREAU STATISTICS (PCBS). "The Palestinian environment to where?" 2010. Retrieved from the Palestinian Central Bureau Statistics website: http://www.pcbs.gov.ps/Portals/_pcbs/ PressRelease/Envirm-DayE.pdf

63. PALESTINIAN RED CRESCENT SOCIETY (PRCS). The Use of Radioactive Uranium in Israeli Military OperationsAn International Humanitarian Law Perspective. 2014. Retrieved From http://www.palestinercs.org/en/adetails. php?aid $=11$

64. PALESTINIAN NATIONAL AUTHORITY (PNA). The Palestinian National Early Recovery and Reconstruction Plan for Gaza 2009-2010. Paper presented at the International Conference in Support of the Palestinian Economy for the Reconstruction of Gaza.

65. KARAEEN M. Air Pollution in Palestine: This Week in Palestine, (164). 2012 Retrieved from http://archive.thisweekinpalestine.com/details. php? $\mathrm{id}=3847 \&$ ed $=211$ \&edid $=211$

66. UNITED NATIONS OFFICE FOR THE COORDINATION OF HUMANITARIAN AFFAIRS OCCUPIED PALESTINIAN TERRITORY (OCHA. Gaza Crisis Appeal, 09 September 2014 Retrieved from: http://www.ochaopt. org/results.aspx?id=4771517.
67. UNITED NATIONS FOR TRAINING AND RESEARCH (UNITAR). Impact of the 2014 Conflict in the Gaza Strip, UNOSAT Satellite Derived Geospatial Analysis. 2014. Retrieved from http://reliefweb.int/sites/reliefweb.int/files/ resources/UNOSAT_Gaza_Report_Web_Final_2014.pdf.

68. ENVIRONMENT QUALITY AUTHORITY (EQA), Palestine. Primary Environmental Assessment of Israeli Invasion on Gaza Strip, 26 august, 2014.

69. EYRE P. Did Richard Goldstone Hide More Sinister Crimes in Gaza? Part 2 - DIME and Uranium Weapons. 2009. Retrieved from http://www.thehandstand.org/archive/ august-september2009/articles/goldstein.htm

70. NEW WEAPONS COMMITTEE "Gaza Strip, Soil Has Been Contaminated Due to Bombings: Population in Danger," press release, December 17, 2009.

71. RAMHI S. The Environmental Impact of the Israeli Settlements on the Occupied Palestinian Territories. 2012. Retrieved from file:///C:/Users/dell/Downloads/ the-environmental-impact-of-israeli-settlements-on-theoccupied-palestinian-territories $\% 20(1)$.pdf

72. GLOBAL NETWORKS FOR RIGHTS AND DEVELOPMENT (GNRD). Israeli Enforcement of Buffer Zone Area in the Gaza Strip: "Most Important Violations Resulting from the Buffer Zone" January 2010 to December 2011. 2011. Retrieved form http://www.gnrd.net/userfiles/ cc/gaza.pdf

73. AL-MONITOR Gaza's Green Spaces Face Constant Threats. 2013. Retrieved from: http://www.al-monitor.com/pulse/tr/ originals/2013/05/gaza-green-spaces-threatened.html

74. ELY M., PITMAN SH. Green Infrastructure Life support for human habitats: The compelling evidence for incorporating nature into urban environments, June 2014. Retrieved from file://C:/Users/dell/Downloads/green_infrastructure_ evidence base 2014\%20(1).pdf

75. PUGH T., MACKENZIE A.J., WHYATT J., HEWITT C. Effectiveness of Green Infrastructure for Improvement of Air Quality in Urban Street Canyons. Environ. Sci. Technol., 46, 7692, 2012.

76. ESCOBEDO F.J., KROEGER T., WAGNER J.E. Urban forests and pollution mitigation: analyzing ecosystem services and disservices. Environmental Pollution. 159 (89), 2078, 2011.

77. ENTRIX. Portland's Green Infrastructure: Quantifying the Health, Energy, and Community Livability Benefits, Feb 2010. Retrieved from https://www.portlandoregon.gov/bes/ article/298042

78. KAZMIERCZAK A., CARTER J. Adaptation to climate change using green and blue infrastructure. A database of case studies. 2010.

79. TIWARY A., SINNETT D., PEACHEY C., CHALABI Z., VARDOULAKIS, S., FLETCHER T., LEONARDI G., GRUNDY C., AZAPAGIC A., HUTCHINGS T.R. An integrated tool to assess the role of new planting in $\mathrm{PM}_{10}$ capture and the human health benefits: a case study in London. Environ. Pollut. 157, 2645, 2009. 